\title{
Vapour-phase efficacy of selected essential oils individually and in combination against Aspergillus flavus, $A$. niger, Fusarium proliferatum, and Curvularia lunata
}

\author{
Alex Ahebwa ${ }^{1}$, Rachsawan Mongkol ${ }^{1}$, Paranee Sawangsri ${ }^{2}$ and Mana Kanjanamaneesathian ${ }^{1, *}$ \\ ${ }^{1}$ Faculty of Animal Science and Agricultural Technology, Silpakorn University, Phetchaburi IT campus, Cha-Am, \\ Phetchaburi, 76120, Thailand \\ ${ }^{2}$ Biotechnology Research and Development Office, Department of Agriculture, Ministry of Agriculture and \\ Cooperatives, 12110, Thailand \\ *Corresponding author: Kanjanamaneesat_m@su.ac.th \\ (Original submission received 24 April 2020; accepted in revised form 9 November 2020)
}

\begin{abstract}
Grain storage plays a crucial role in ensuring food security to Thai farmers so sustainable protection methods against deleterious microorganisms, such as fungi, are necessary. Essential oils (EOs) have demonstrated broad-spectrum fumigant antifungal activity against most storage fungi that are problematic in Thailand. Four storage fungi (Aspergillus flavus, A. niger, Curvularia lunata and Fusarium proliferatum) were isolated from dried rice and corn grains (stored for at least six months). EOs were extracted by hydrodistillation from clove buds (Syzygium aromaticum), fruit peel and leaves of makrut lime (Citrus hystrix), eucalyptus leaves (Eucalyptus sp.) and lemongrass stems (Cymbopogon citratus). The fungi inoculated on PDA in plastic cups were exposed to each EO vapour originating from paper disc attached in the lids in an inverted position. The minimum inhibitory concentration (MIC) for each EO was determined. Selected MICs were combined in a binary manner and similarly tested against the fungi. Fractional inhibitory concentration indices (FICI) were determined for each combination. Lemongrass and makrut lime leaf EOs were the most effective with MICs of $0.09 \mu \mathrm{L} / \mathrm{mL}$ against Curvularia lunata and 0.19-0.28 $\mu \mathrm{L} / \mathrm{mL}$ against A. flavus, A. niger and $F$. proliferatum. Eucalyptus oil produced the least effective vapour (MIC 0.56-0.74 $\mu \mathrm{L} / \mathrm{mL}$ ) against all tested pathogens. A combination of lemongrass and makrut lime leaf EOs was partially synergistic against $A$. niger $(\mathrm{FICI}=0.75)$ but was fully synergistic against the other three fungi tested (FICI=0.5). The EOs from lemongrass and makrut lime leaf have potential to suppress the growth of the four grain-storage fungi tested.
\end{abstract}

Keywords Grains, essential oil vapour, storage fungi, mycelial growth, synergism, Thailand

\section{INTRODUCTION}

Essential oils (EOs), also known as "volatile oils", are steadily emerging as crop, food protectants and preservatives because of the increased public demand for safer and natural food. Essential oils are biosynthetic secondary metabolites that occur in various parts of plants such as roots, rhizomes, stems, leaves, flowers, flower buds, fruits and seeds. They are composed of various compounds (in structure and function) that give them their beneficial characteristics (Burt 2004). Application of essential oils in agriculture has been recently reported as antifungal (Hossain et al. 2016), antimycotic (Esper et al. 2014), antibacterial (Goni et al. 2009; Siddiqua et al. 2015), and insecticidal agents (Jiang et al. 2016; Kim et al. 2016). Beneficial aspects of EOs include additive/synergistic effects when used in combination, broad-spectrum activity, edibility, and low toxicity, which have contributed to increased research on EOs worldwide (Mandras et al. 2016; da Silva Gündel et al. 2019).

Cereal grains are important foods globally. Rice (Oryza sativa), corn (Zea mays) and wheat (Triticum spp.) provide at least $30 \%$ of the daily food calories to more than 4.5 billion people in developing countries (OECD/FAO 2019). Rice and corn are the most produced cereal crops in Thailand with rice as staple food and corn as a major raw-material in feed industry (FAO 2020). Thailand is world's second largest exporter of rice, and sixth largest producer globally (Krungsri 2019).

Microorganisms, especially fungi, are hard to control by the storage methods employed by most grain retailers and small-scale farmers, especially in tropical climates where high humidity favours fungal growth (Mendoza et al. 2017). Fungi such as Aspergillus flavus, A. niger, Fusarium sp. and Curvularia lunata are commonly isolated pathogens from rice and corn grains in Thailand (Pitt et al. 1993, 1994; Lapmak et al. 2009; Jitjak \& Sanoamuang 2019). Some fungal species such as $A$. flavus isolated from Thai grains were concomitant with carcinogenic, mutagenic and immunosuppressing aflatoxins (Tansakul et al. 2013; Tran-Dinh et al. 2014). Fusarium proliferatum is a major producer of fumonisins (Proctor et al. 2009) while Curvularia lunata is a major causative agent of grain discolouration disease, a complex and economically important disease of rice in Thailand (Ashfaq et al. 2017; CABI 2020). 
Synthetic chemical fungicides applied by grain coating/ mixing and fumigation have been used effectively to control fungi and their metabolites (Kumar \& Kalita 2017). Synthetic fungicides such as mancozeb [manganese ${ }^{2+}$ ethane-1,2-diylbis(dithiocarbamate) zinc ethane-1,2diylbis(dithiocarbamate)] are the major grain protection option available in Thailand (Tawatsin 2015). However, they are expensive and have been reported to pose various health risks to Thai farmers and agricultural workers (Corsini et al. 2005; Panuwet et al. 2008; Thundiyil et al. 2008; Tawatsin 2015; Kongtip et al. 2017; Dhananjayan \& Ravichandran 2018). For agricultural sustainability, alternatives are needed and plant-based biopesticides are potential candidates if they can control storage fungi individually or be integrated with other sustainable controls.

Thailand has a rich biodiversity of medicinal plants (Bullangpoti 2009; Phumthum et al. 2018) and various published studies have shown EOs to be effective against storage fungi (Sukatta et al. 2008; Thobunluepop et al. 2008; Jantapan et al. 2017). EOs are generally acceptable as safe for use in food. However, concerns for their potential health risks, such as liver toxicity and skin allergies, have attracted various food and drug regulatory institutions to limit acceptable daily intakes when added to food (Baser \& Buchbauer 2015; Hashemi et al. 2017). In a recent review, various studies on hepatotoxicity of EOs reported acute liver injury and centrilobular necrosis by some common monoterpenes and sesquiterpenes including citral - a major chemical constituent of lemongrass oil (Zárybnický et al. 2018). Strategies that limit quantities of EOs applied without interfering with their efficacy are an important area of research.

EOs are complex mixtures of volatile secondary metabolites which can vaporise at ambient temperatures (Burt 2004). Treating grains with EO vapours has the potential to be an appropriate delivery system because control efficacy can be achieved with a reduced application quantity (Tyagi \& Malik 2011; Avila-Sosa et al. 2012; Velázquez-Nuñez etal.2013). Moreover, volatile compounds in vapour are reported to act additively/synergistically to increase the efficacy against microorganisms which further reduces the quantity required to control target microorganisms (Edris \& Farrag 2003; Stević et al. 2014; Nikkhah et al. 2017; Ji et al. 2019). Extensive reviews for the antifungal activity of EOs (Nazzaro et al. 2017) as well as their dispensation by vapour contact (Laird \& Phillips 2012) have been published but few studies have been conducted to evaluate the efficacy of EO vapours applied in combination and, to the best of our knowledge, none have been reported for the combination of, for example, lemongrass and makrut lime EOs by vapour contact against A. flavus, A. niger, Curvularia lunata and F. proliferatum, the most widely spread and damaging storage fungi of corn and rice.

We hypothesised that EO vapours would significantly inhibit mycelial growth and that their combinations would produce a synergistic action against the tested fungi. Therefore, the aim of this study was to assess the in vitro efficacy of selected EO vapours applied both individually and in combination to inhibit the mycelial growth of $A$. flavus, A. niger, Curvularia lunata and F. proliferatum.

\section{MATERIALS AND METHODS}

\section{Collection and preparation of plant materials}

Plant materials were collected from the areas of Cha-Am district, Phetchaburi Province, Thailand during January 2019. Four species (Table 1), with well documented antimicrobial activity (Bakkali et al. 2008), were selected. The plant materials were transferred to the laboratory and prepared for EO extraction on the same day as follows: fresh makrut lime fruits were washed under running tap water and then air dried. The green skin of these fruits was peeled off with a knife and cut into $3 \mathrm{~mm} \times 3 \mathrm{~mm} \times 1 \mathrm{~mm}$ cubes. Fresh leaves of makrut lime, eucalyptus, and fresh stems of lemongrass were individually washed under running tap water and these samples were air dried for 30 min before being cut into small pieces (approximately $3 \mathrm{~mm}$ x $2 \mathrm{~mm}$ x $0.5 \mathrm{~mm}$ ). Dried clove buds were ground into a particulate powder using a blender (Moulinex, Optiblend, France). The weight of each sample (enough to produce required EO yield for all tests) is given in Table 1.

Table 1 Plant materials used for extracting essential oils, sample weight and yield of essential oil (EO)

\begin{tabular}{|c|c|c|c|c|c|}
\hline Plant & Scientific name & Plant part & Source & $\begin{array}{l}\text { Fresh sample } \\
\text { weight }(\mathrm{g})\end{array}$ & $\begin{array}{l}\text { EO yield (\%, } \\
\text { v/fresh w) }\end{array}$ \\
\hline Clove & Syzygium aromaticum & Buds & $\begin{array}{l}\text { Purchased from a local market in } \\
\text { HuaHin }\end{array}$ & 222.3 & 4.43 \\
\hline Eucalyptus & Eucalyptus sp. & Leaves & $\begin{array}{l}\text { Collected from the tree at Silpakorn } \\
\text { University, Cha-Am }\end{array}$ & 425.7 & 0.66 \\
\hline Makrut lime & Citrus hystrix & Peel & $\begin{array}{l}\text { Collected from a backyard orchard } \\
\text { in HuaHin }\end{array}$ & 244.5 & 3.40 \\
\hline Makrut lime & Citrus hystrix & Leaves & $\begin{array}{l}\text { Collected from a backyard orchard } \\
\text { in HuaHin }\end{array}$ & 330.8 & 0.59 \\
\hline Lemongrass & Cymbopogon citratus & Stems & $\begin{array}{l}\text { Provided in-kind from a banana } \\
\text { garden in Cha-Am }\end{array}$ & 1000.1 & 0.53 \\
\hline
\end{tabular}




\section{Essential oil extraction}

Essential oils were extracted by hydrodistillation using Clevenger-type apparatus. The prepared plant materials, as described above, were individually added into a two-neck boiling flask (1-L capacity) containing five to eight porcelain boiling chips and filled up to half mark. Distilled water was added until the plant material was just submerged. The flask was then placed onto a heater and the entire setup was fitted to a Clevenger-type glass apparatus and a condenser. EOs were extracted from the plant materials by heating to a temperature of $120^{\circ} \mathrm{C}$ until the first condensate drop was obtained, after which the temperature was maintained at $60^{\circ} \mathrm{C}$ for the rest of the extraction period (Handa 2008). The process was repeated until all the pre-weighed plant material was used. Heating was stopped when no more EO was emitted into the distillate receiver (100-210 mins).

The EO layer was separated from aqueous distillate using a separating funnel, then dried using anhydrous sodium sulphate. The pure EO layer was pipetted into pre-weighed glass bottles, then weighed and the percentage yield calculated. The pure EOs were kept in a refrigerator at $4-8^{\circ} \mathrm{C}$ until further use.

\section{Isolation of fungi}

Four fungi were isolated from three grain samples with a predetermined moisture content (MC). Two corn samples [1 - from the laboratory at the Faculty of Animal Science and Agricultural Technology (ASAT), Silpakorn University (SU), Phetchaburi IT campus, Cha-Am $(\mathrm{MC}=12.4)$; and $2-$ from a retail shop at a market in Cha-Am $(M C=10.0)]$ and one rice sample from the same retail shop $(M C=11.3)$. The $\mathrm{MC}$ of the samples was determined by oven drying method and calculated on a weight-loss basis.

One hundred and fifty grains of each sample were surface sterilised in $1 \% \mathrm{v} / \mathrm{v}$ sodium hypochlorite $(\mathrm{NaOCl})$ for $5 \mathrm{~min}$ with constant stirring. Next, these samples received three 5 -min washes in sterile distilled water and then were dried between two layers of sterile tissue paper for $30 \mathrm{~min}$ and immediately used for further study.

The fungi were isolated by plating each grain sample onto potato dextrose agar (PDA) (potato dextrose broth (PDB) plus Agar, HiMedia, India) and on moistened filter paper (Whatman No. 1; $9 \mathrm{~mm}$ diameter) in sterile glass Petri dishes as described by (Tsedaley \& Adugna 2016). Twenty grains of each sample were plated on PDA and 10 grains on moistened filter per one Petri dish. There were four replications for each grain sample and each isolation technique. The grain samples were incubated for seven days at room temperature $\left(26-32^{\circ} \mathrm{C}\right)$ with $12: 12 \mathrm{~h}$ of light/dark.

Fungal growth was checked daily using a stereo microscope. Fungal isolates were tentatively identified based on their colony appearance and growth rate. After seven days of incubation, fungal characteristics were observed under a compound microscope by the wet-mount technique (Klich \& Pitt 1988).

\section{Identification of fungi}

The four isolates of fungi used in this experiment were identified based on colony appearance and morphological characteristics (Dutta \& Hussain 1959; Albores et al. 2014;
Nyongesa et al. 2015). The identified fungal isolates were subcultured onto PDA in Petri dishes. These fungal cultures were incubated on a laboratory bench at room temperature $\left(26-32^{\circ} \mathrm{C}\right)$ for seven days. The pure cultures were then stored in a refrigerator at $4{ }^{\circ} \mathrm{C}$ for further identification using DNA sequencing.

Molecular identification was carried out by sequence analysis of the internal transcribed spacer (ITS1 and ITS2) regions of ribosomal DNA (rDNA). Genomic DNA was extracted from mycelia of fungal isolates using QIAamp ${ }^{\circledR}$ DNA Mini Kit (Qiagen) protocol. PCR was used to amplify the internal transcribed spacer regions 1 and 2 of the rRNA gene cluster using forward primer sequence ITS-1 5' TCCGTAGGTGAACCTGCGG - 3' and reverse primer sequence ITS-4 5' - TCCTCCGCTTATTGATATGC - 3' (White et al. 1990).

PCR amplifications were performed in a total volume of $50 \mu \mathrm{L}$ by mixing $200 \mathrm{ng}$ of the template DNA with $0.6 \mu \mathrm{M}$ of each primer, $25 \mu \mathrm{L}$ of $2 x$ GoTaq ${ }^{\circledR}$ Green Master Mix. The PCR thermal cycle was: an initial denaturation of $2 \mathrm{~min}$ at $95^{\circ} \mathrm{C}$, followed by 30 cycles $\left(30 \mathrm{sec}\right.$ at $94^{\circ} \mathrm{C}, 30 \mathrm{sec}$ at $55^{\circ} \mathrm{C}$ and $2 \mathrm{~min}$ at $72^{\circ} \mathrm{C}$ ) with a final extension of $5 \mathrm{~min}$ at $72^{\circ} \mathrm{C}$. Aliquots $(3 \mu \mathrm{L})$ were analysed by electrophoresis in $1.5 \%$ (wt/vol) agarose gel in $1 \times$ TBE buffer. The sequencing data were compared against the GenBank database (http:// www.ncbi.nlm.nih.gov/BLAST/), where a nucleotide blast program identified homology between the PCR fragments and sequences deposited in the GenBank database.

Fungus obtained from corn sample 1 was identified as Aspergillus flavus with $100 \%$ similarity (accession number MT529482.1). The fungus from the rice sample was identified as Curvularia lunata with $99.64 \%$ similarity (accession number KX156939.1). Two fungi were obtained from corn sample 2. These were identified as Fusarium proliferatum with 99.62\% similarity (accession number MK748309.1) and as $A$. niger with $100 \%$ similarity (accession number MN636772.1).

\section{Antifungal assay using single essential oils}

A colony of each test fungi grown on PDA was exposed to each EO vapour by the inverted Petri dish method (Boukhatem et al. 2014). EOs from leaves of makrut lime (ML), peels of makrut lime (MP), leaves of eucalyptus (EU), stems of lemongrass (LG) and dried buds of clove (C) were tested for their antifungal activity against Aspergillus flavus, A. niger, Curvularia lunata and Fusarium proliferatum.

The assay was carried out in 30-mL circular sterile plastic cups with lids. Hot sterile PDA liquid ( $3 \mathrm{~mL}$ ) was added to each cup using a sterile syringe and allowed to cool and solidify. A mycelial plug (5-mm diameter) was cut from edge of a 7-day-old fungal colony with a sterile corkborer and transferred onto the solidified PDA using a sterile L-shaped needle. A sterile filter paper disc (Whatman No. 1, 6-mm diameter) was attached to the underside of the lid of each cup with a sterile double-sticking tape. Aliquots $(5,10$ or $20 \mu \mathrm{L}$ ) of pure EOs were each individually dispensed to the filter paper discs using a micropipette (Velázquez-Nuñez et al. 2013), and the cups were immediately closed with their lids to prevent the volatile compounds from escaping. For nil control treatment, EO was not added to the paper disc. The cups were incubated upside down at room temperature 
$\left(26-32^{\circ} \mathrm{C}\right)$ for $96 \mathrm{~h}$ with $12: 12 \mathrm{~h}$ of light/dark on a table in the laboratory. The experiment was arranged in a completely randomised design (CRD) with three replications for each treatment.

After $96 \mathrm{~h}$ of incubation (when the fungal colony in each control had reached the edges of the cup), antifungal activity of each EO was evaluated by measuring colony diameter twice diagonally. Percentage mycelial growth inhibition was calculated using the formula proposed by Ambindei et al. (2017) as follows:

$$
\text { Percent Inhibition }=\left(M_{c}-M_{t}\right) / M_{c} \times 100
$$

Where $\mathrm{M}_{\mathrm{c}}=$ averaged colony diameter $(\mathrm{mm})$ for control, $\mathrm{M}_{\mathrm{t}}=$ averaged colony diameter ( $\mathrm{mm}$ ) for treatment.

\section{Minimum inhibitory concentration (MIC)}

The MIC was defined as the smallest concentration of the EO vapours that was able to completely inhibit mycelial growth after $72 \mathrm{~h}$ of incubation (Inouye et al. 2001). From the antifungal assay above, the smallest inhibitory dose (SID; i.e. volume of EO that completely inhibited fungal mycelial growth) for each fungus was diluted thrice to $75 \%$ of SID, $50 \%$ of SID and $25 \%$ of SID. The same inoculation and treatment procedure were maintained as described above but incubation period reduced to $72 \mathrm{~h}$ (Inouye et al. 2001; Stević et al. 2014). The dose in cups that showed no visible growth was determined as the minimum inhibitory dose, MIC was calculated as follows:

$$
\begin{aligned}
\mathrm{MIC}= & \text { minimum inhibitory dose }(\mu \mathrm{L}) / \\
& \text { volume of air above the oil in the cup }(\mathrm{mL})
\end{aligned}
$$

The assumption made was that all the EO in the filter paper disc had evaporated into the headspace in the cup.

\section{Antifungal assay with combination of essential oils}

Based on the efficacy of MIC, the EOs of LG, EU, MP and ML, were selected for a synergism test. Each fungus ( $A$. flavus, $A$. niger, Curvularia lunata and $F$. proliferatum) was exposed to vapour of two EOs within the same cup.

Two sterile filter paper discs were attached underneath the lid of a cup containing sterile PDA inoculated with a mycelial plug of each fungus. The selected EOs were individually applied to the sterile filter paper discs in the combinations LG:EU, LG:MP, LG:ML, ML:MP, ML:EU so that two EOs shared the same atmosphere in the cup (Arrebola et al. 2010). The chosen EOs were based on their efficacy, availability and the ease of preparation of the raw plant materials. Clove EO was not tested due to unsatisfactory efficacy, in addition to being a costly raw material while a EU and MP combination was unwarranted due to high MICs.

This assay was carried out based on the procedure developed by Ji et al. (2019) with some modifications. The treatments LG:EU, LG:MP, LG:ML, ML:MP and ML:EU were prepared in the combined MIC dilutions of 100:0, 75:25, 50:50, 25:75, and 0:100, with pure EOs. The control was prepared with no EO and there were three replications for each treatment. Each cup that received two discs of EOs was immediately sealed and incubated upside down at room temperature $\left(26-32^{\circ} \mathrm{C}\right)$ for $96 \mathrm{~h}$ with $12: 12 \mathrm{~h}$ of light/ dark. After this time, mycelial growth inhibition in each cup was evaluated by measuring the colony diameter twice diagonally, the average colony diameter was determined and percent mycelial growth inhibition was determined using the formula described previously. The smallest treatment dose in the cups with no visible mycelial growth was recorded as minimum fractional inhibitory doses of the EOs and were used to calculate MIC for the EOs in combination.

The MICs of EOs in combination $\left(\mathrm{MIC}_{\mathrm{X}}\right)$ in relation to the MIC of each EO alone ( IIC $_{\mathrm{Y}}$ ) were used to calculate the fractional inhibitory concentration (FIC) and then fractional inhibitory concentration index (FICI), using the following formula as previously described (Sukatta et al. 2008):

For a combination of two EOs A and B:

$$
\begin{aligned}
& \mathrm{FIC}_{\mathrm{A}}=\mathrm{MIC}_{\mathrm{X}(\mathrm{A}+\mathrm{B})} / \mathrm{MIC}_{\mathrm{YA},} \text { and } \mathrm{FIC}_{\mathrm{B}}=\mathrm{MIC}_{\mathrm{X}(\mathrm{A}+\mathrm{B})} / \mathrm{MIC}_{\mathrm{YB}} \\
& \mathrm{FICI}=\mathrm{FIC}_{\mathrm{A}}+\mathrm{FIC}_{\mathrm{B}}
\end{aligned}
$$

Where:

$$
\begin{aligned}
& \mathrm{MIC}_{\mathrm{X}(\mathrm{A}+\mathrm{B})}=\text { MIC of EOs A and B in combination; } \\
& \mathrm{MIC}_{\mathrm{YA}}=\text { MIC of EO A alone; } \\
& \mathrm{MIC}_{\mathrm{YB}}=\text { MIC of EO B alone; } \\
& \mathrm{FIC}_{\mathrm{A}}=\text { FIC of essential oil A, and } \\
& \mathrm{FIC}_{\mathrm{B}}=\text { FIC of essential oil B. }
\end{aligned}
$$

\section{Data analysis}

The data collected was subjected to a One-way analysis of variance (ANOVA) using $\mathrm{R}$ programme (Venables et al. 2019) computer software package (version 3.1.0). The mean values were compared using the Duncan's Multiple Range Test, $P \leq 0.01$.

\section{RESULTS}

\section{Antifungal activity with single essential oils}

The vapour from ML, MP, EU, LG and C EOs were assessed for their mycelial growth inhibitory potential against $A$. flavus, A. niger, Curvularia lunata and F. proliferatum. Results (Table 2) showed that all EOs had an inhibitory activity against fungal mycelial growth. LG and ML EOs were the most effective against all pathogens at all levels of dosage. LG at $5 \mu \mathrm{L}$ (lowest dose) completely inhibited all pathogens except A. flavus (89\%) while ML completely inhibited A. flavus and Curvularia lunata at the same dose. EU and MP EO vapours were less inhibitory especially against $A$. niger $(7.5-45 \%$ and $17-55 \%$ respectively) when compared to either C, ML or LG EO vapours.

With the above results, MIC (vol/vol of air) of each EO were determined and presented in Table 3. LG oil and ML oil showed the lowest MIC values $(0.09-0.19 \mu \mathrm{L} / \mathrm{mL} \& 0.09-$ $028 \mu \mathrm{L} / \mathrm{mL}$ respectively), while the MIC of EU oil was $0.56-$ $0.74 \mu \mathrm{L} / \mathrm{mL}$ for all pathogens (Table 3 ). 
Table 2 Mean $( \pm \mathrm{SE})$ percentage of mycelial growth inhibition of fungi versus the control treatment, where fungi were grown in the absence of essential oils, after $96 \mathrm{~h}$ of incubation at 26$32^{\circ} \mathrm{C}$ with $12: 12 \mathrm{~h}$ of light/dark. Means in each column with the same letter are not significantly different at $P \leq 0.01$ by the Duncan's Multiple Range test.

\begin{tabular}{|c|c|c|c|c|c|}
\hline \multirow[t]{2}{*}{ Essential oil } & \multirow[t]{2}{*}{ Dose $(\mu \mathrm{L})$} & \multicolumn{4}{|c|}{ Percent mycelial growth inhibition } \\
\hline & & A. flavus & A. niger & F. proliferatum & C. lunata \\
\hline \multirow[t]{3}{*}{$\mathrm{C}$} & 5 & $42.9 \pm 2.7^{\text {cde }}$ & $35.0 \pm 6.4^{\mathrm{bc}}$ & $37.9 \pm 3.2^{c}$ & $73.3 \pm 1.1^{b}$ \\
\hline & 10 & $54.6 \pm 4.4^{\mathrm{cd}}$ & $55.4 \pm 6.1^{\mathrm{abc}}$ & $63.3 \pm 4.0^{\mathrm{b}}$ & $75.4 \pm 0.4^{\mathrm{b}}$ \\
\hline & 20 & $81.7 \pm 9.2^{\mathrm{ab}}$ & $77.4 \pm 11.5^{\mathrm{ab}}$ & $100.0 \pm 0.0^{\mathrm{a}}$ & $100.0 \pm 0.0^{\mathrm{a}}$ \\
\hline \multirow[t]{3}{*}{ EU } & 5 & $34.2 \pm 4.6^{\mathrm{de}}$ & $7.5 \pm 0.8^{\mathrm{c}}$ & $24.2 .5 \pm 1.2^{\mathrm{cd}}$ & $30.4 \pm 4.7^{c}$ \\
\hline & 10 & $62.1 \pm 3.2^{\mathrm{bc}}$ & $9.1 \pm 4.4^{c}$ & $35.2 \pm 0.8^{c}$ & $60.4 \pm 8.1^{b}$ \\
\hline & 20 & $100.0 \pm 0.0^{\mathrm{a}}$ & $45.0 \pm 28.0^{\mathrm{bc}}$ & $57.8 \pm 3.9^{b}$ & $75.0 \pm 4.1^{b}$ \\
\hline \multirow[t]{3}{*}{ LG } & 5 & $89.0 \pm 11.0^{\mathrm{a}}$ & $100.0 \pm 0.0^{\mathrm{a}}$ & $100.0 \pm 0.0^{\mathrm{a}}$ & $100.0 \pm 0.0^{\mathrm{a}}$ \\
\hline & 10 & $100.0 \pm 0.0^{\mathrm{a}}$ & $100.0 \pm 0.0^{\mathrm{a}}$ & $100.0 \pm 0.0^{\mathrm{a}}$ & $100.0 \pm 0.0^{\mathrm{a}}$ \\
\hline & 20 & $100.0 \pm 0.0^{\mathrm{a}}$ & $100.0 \pm 0.0^{\mathrm{a}}$ & $100.0 \pm 0.0^{\mathrm{a}}$ & $100.0 \pm 0.0^{\mathrm{a}}$ \\
\hline \multirow[t]{3}{*}{ ML } & 5 & $100.0 \pm 0.0^{\mathrm{a}}$ & $82.5 \pm 15.2^{\mathrm{ab}}$ & $35.0 \pm 6.9^{c}$ & $100.0 \pm 0.0^{\mathrm{a}}$ \\
\hline & 10 & $100.0 \pm 0.0^{\mathrm{a}}$ & $100.0 \pm 0.0^{\mathrm{a}}$ & $100.0 \pm 0.0^{\mathrm{a}}$ & $100.0 \pm 0.0^{\mathrm{a}}$ \\
\hline & 20 & $100.0 \pm 0.0^{\mathrm{a}}$ & $100.0 \pm 0.0^{\mathrm{a}}$ & $100.0 \pm 0.0^{\mathrm{a}}$ & $100.0 \pm 0.0^{\mathrm{a}}$ \\
\hline \multirow[t]{3}{*}{ MP } & 5 & $20.4 \pm 5.3^{\mathrm{e}}$ & $17.9 \pm 11.6^{\mathrm{c}}$ & $20.4 \pm 1.7^{c d}$ & $40.8 \pm 4.1^{c}$ \\
\hline & 10 & $52.9 \pm 6.0^{\mathrm{cd}}$ & $47.9 \pm 3.2^{\mathrm{abc}}$ & $35.4 \pm 7.4^{\mathrm{c}}$ & $78.8 \pm 8.4^{b}$ \\
\hline & 20 & $100.0 \pm 0.0^{\mathrm{a}}$ & $55.4 \pm 3.6^{\mathrm{abc}}$ & $85.1 \pm 7.6^{a}$ & $100.0 \pm 0.0^{\mathrm{a}}$ \\
\hline
\end{tabular}

$C=$ Clove, $E U=$ eucalyptus, $L G=$ lemongrass, $M L=$ makrut lime leaf, $M P=$ makrut lime peel

\section{Essential oils in combination}

Only the combination of LG and ML EOs exerted synergism (FICI $=0.5 \& 0.75$ ) against all the tested fungi (Table 4). The combination of LG and MLEOs exhibited full synergistic effect against F. proliferatum, Aspergillus flavus and Curvularia lunata and partial synergism against $A$. niger. A combination of LG and EU EOs was fully synergistic against $A$. niger. Oils of ML with EU had full synergism against Curvularia lunata (Table 4).

Table 3 Minimum Inhibitory Concentrations (MIC) for the EO vapours against the fungal mycelium growth after $72 \mathrm{~h}$ of incubation at $26-32^{\circ} \mathrm{C}$ with $12: 12 \mathrm{~h}$ of light/dark.

\begin{tabular}{|c|c|c|c|c|}
\hline \multirow{2}{*}{$\begin{array}{l}\text { Essential } \\
\text { oil }\end{array}$} & \multicolumn{4}{|c|}{ MIC $(\mu \mathrm{L} / \mathrm{mL}$ of air $)$} \\
\hline & $\begin{array}{l}\text { A. } \\
\text { flavus }\end{array}$ & $\begin{array}{l}\text { A. } \\
\text { niger }\end{array}$ & $\begin{array}{l}F \\
\text { proliferatum }\end{array}$ & $\begin{array}{l}\text { C. } \\
\text { Iunata }\end{array}$ \\
\hline $\mathrm{C}$ & 0.37 & 0.37 & 0.56 & 0.37 \\
\hline EU & 0.56 & $>0.74$ & 0.56 & 0.56 \\
\hline ML & 0.19 & 0.19 & 0.28 & 0.09 \\
\hline MP & 0.56 & 0.74 & 0.56 & 0.28 \\
\hline LG & 0.19 & 0.19 & 0.19 & 0.09 \\
\hline
\end{tabular}

$C=$ Clove, $E U=$ eucalyptus, $L G=$ lemongrass, $M L=$ makrut lime leaf, $M P=$ makrut lime peel

\section{DISCUSSION}

Aspergillus flavus, A. niger and F. proliferatum were isolated from corn grains while Curvularia lunata was isolated from rice grains. Aspergillus flavus has been isolated from Thai corn before (Tran-Dinh et al. 2014). Marin et al. (1998) reported co-occurrence of $A$. flavus with $F$. proliferatum on Thai corn. Pitt et al. (1993) investigated 154 samples of Thai corn and at least $85 \%$ were infected with $A$. flavus while the incidence of A. niger was 64\%. Curvularia lunata was a dominant isolate from various parts of Thai rice plants including the grains (50\% occurrence) (Seephueak et al. 2019). Pitt et al. (1994) reported a 2-20\% incidence of Curvularia lunata in paddy rice from retail stores in Thailand. The current study investigated the vapour-phase antifungal activity of selected EOs individually and in combination against these common grain fungi.

The EO vapour from ML inhibited the mycelial growth of A. flavus and Curvularia lunata, and significantly affected the growth of $A$. niger at the lowest dose tested ( $5 \mu \mathrm{L}$ ) (Table 2). Srisukh et al. (2012) reported that citronellal (3,7-dimethyloct-6-enal) was the major component (at about $80 \%$ ) in makrut leaf oil based on the analysis using gas chromatography-mass spectrometry. Vapour application of citronellal, extracted from Cymbopogon nardus, completely inhibited the growth of Aspergillus sp., Penicillium sp. and Eurotium sp. at a dose of $112 \mathrm{mg} / \mathrm{L}$ of air (Nakahara et al. 2013). Different plant parts from the same plant species 
Table 4 Fractional Inhibitory Concentrations for individual EO vapours and the Fractional Inhibitory Concentration Indices $^{1,2}$ for combinations of EO vapours against the study fungi calculated from the MICs.

\begin{tabular}{|c|c|c|c|c|c|c|c|c|c|c|c|c|c|}
\hline \multirow{2}{*}{\multicolumn{2}{|c|}{ Essential oils }} & \multicolumn{12}{|c|}{ Fungus tested } \\
\hline & & \multicolumn{3}{|c|}{ A. flavus } & \multicolumn{3}{|c|}{ F proliferatum } & \multicolumn{3}{|c|}{ A. niger } & \multicolumn{3}{|c|}{ C. lunata } \\
\hline $\mathbf{A}$ & B & $\mathrm{FIC}_{\mathrm{A}}$ & $\mathrm{FIC}_{\mathrm{B}}$ & FICI & $\mathrm{FIC}_{\mathrm{A}}$ & FIC $_{\mathrm{B}}$ & FICI & $\mathrm{FIC}_{\mathrm{A}}$ & FIC $_{\text {в }}$ & FICI & $\mathrm{FIC}_{\mathrm{A}}$ & $\mathrm{FIC}_{\mathrm{B}}$ & FICI \\
\hline LG & EU & 0.25 & 0.75 & 1.00 & 0.25 & 0.50 & 0.75 & 0.25 & 0.25 & 0.50 & 0.75 & 0.5 & 1.25 \\
\hline LG & MP & 0.25 & 0.75 & 1.00 & 0.25 & 0.25 & 0.50 & 0.25 & 0.25 & 0.50 & 0.25 & 0.75 & 1.00 \\
\hline LG & ML & 0.25 & 0.25 & 0.50 & 0.25 & 0.25 & 0.50 & 0.25 & 0.50 & 0.75 & 0.25 & 0.25 & 0.50 \\
\hline ML & EU & 0.75 & 0.50 & 1.25 & 0.75 & 0.5 & 1.25 & 0.75 & 0.75 & 1.50 & 0.25 & 0.25 & 0.50 \\
\hline ML & MP & 0.75 & 0.50 & 1.25 & 0.25 & 0.5 & 0.75 & 0.75 & 0.75 & 1.50 & 0.25 & 0.50 & 0.75 \\
\hline
\end{tabular}

${ }^{1}$ FICI $\leq 0.5$ was considered synergistic; FICI $\geq 0.5 \leq 1$ partially synergistic; FICI $>1$ no interaction (Ji et al. 2019)

${ }^{2} A \& B$ represent the different essential oils in combination; $L G=$ lemongrass, $E U=$ eucalyptus, $M L=$ makrut lime leaf, and $M P=$ makrut lime peel

(Citrus hystrix), showed differences both in the percent yield of the EO and their efficacy to inhibit the fungi (Tables 1 \& 2). The study conducted by Azhdarzadeh and Hojjati (2016) reported difference in EO chemical composition of the leaf, ripe and unripe fruit peels of Citrus aurantium obtained by hydro-distillation and even their antibacterial activity was different with peels producing a higher efficacy than the leaf.

The EO vapour from LG completely inhibited the mycelial growth of all tested fungi at the lowest dose (Table 2), although percent yield of the essential oil of plant was quite low (Table 1). Lemongrass oil was reported to contain approximately $\quad 65-85 \%$ citral (3,7-dimethylocta-2,6dienal) and this substance was inhibitory to Candida sp., the causal agents of the superficial mycoses of the skin in human (Silva et al. 2008). Wang et al. (2019) reported that citral completely suppressed mycelial growth of Alternaria alternata at minimum inhibitory concentration (MIC) of $0.25 \mu \mathrm{L} / \mathrm{mL}$ and inhibited more than $97 \%$ of mycotoxin that was produced by this fungus. Plant pathogenic fungi in peanut (Arachis hypogaea), such as Alternaria alternata, Aspergillus flavus, Curvularia lunata, F. moniliforme, F. pallidoroseum, and Phoma sorghina, were completely inhibited by citral in paper disc agar diffusion assays (Kishore et al. 2007). Tang et al. (2018) also found that citral was also suppressive to growth of Aspergillus flavus and Aspergillus ochraceus, two common grain pathogens.

Clove EO vapour showed antifungal activity against all the tested fungi (Table 2). However, although clove bud had percent yield of the EO more than the other plant materials (Table 1), the efficacy of its EO vapour to inhibit the mycelial growth of the fungi was not as good as that of lemongrass stem and makrut lime leaf (Table 2). Aguilar-González et al. (2015) reported that the EO of clove in vapour phase was effective in inhibiting Botrytis cinerea in strawberries. Clove oil was also reported to be highly inhibitory to the conidial germination of Alternaria alternata, Aspergillus niger, Aspergillus flavus, Curvularia lunata, Fusarium moniliforme, F. oxysporum f. sp. ciceri, F. pallidoroseum and F. udum, the fungal plant pathogens of peanut (Arachis hypogaea) (Kishore et al. 2007). Eugenol (2-methoxy-4-(prop-2-en-1yl)phenol), known to possess antifungal activity, has been reported to be one of the ingredients in the essential oil of clove (Beg \& Ahmad 2002). However, the cost of this raw material is significantly higher than either lemongrass or makrut lime leaf, which can be accessed locally in all parts of Thailand.

The combination of LG and ML EOs completely suppressed the growth of Aspergillus flavus, Curvularia lunata and F. proliferatum and partially suppressed growth of Aspergillus niger while the combination of ML and MP was partially synergistic against Curvularia lunata and $F$. proliferatum but not against the rest of the tested pathogens (Table 4). Similar studies have not been reported before, although synergism was reported for Cymbopogon nardus EO $(\mathrm{MIC}=0.3125 \mu \mathrm{L} / \mathrm{mL}$ ) in combination with Cinnamomum zeylanicum EO (MIC $=0.1563 \mu \mathrm{L} / \mathrm{mL}$ ) applied by vapour contact $($ FICI $=0.50)$ against Penicillium corylophilum $(\mathrm{Ji}$ et al. 2019). The combination of Cymbopogon citratus and Alpinia galanga using the disc-diffusion technique showed synergistic antibacterial activity against Staphylococcus aureus, Pseudomonas aeruginosa, Streptococcus bovis and Candida albicians (Tadtong et al. 2014).

\section{CONCLUSIONS}

The results of our study indicate that EOs from common plants have potential for application as fumigants. The International Rice Research Institute (IRRI) has significantly increased awareness and implementation of hermetic storage systems and in-house silos in south-east Asia including Thailand (Gummert \& Cabardo 2013). Use of airtight containers to store grains by small-scale farmers in Thailand and provide possible application of the EOs as fumigants warrants further study. With increasing regulations against the use of synthetic chemicals, EOs will boost postharvest management in Thailand.

\section{ACKNOWLEDGEMENTS}

The authors are thankful to the Faculty of Animal Science and Agriculture Technology (ASAT), Silpakorn University (SU), Phetchaburi IT campus, Cha-Am, Phetchaburi, Thailand for providing the laboratory facility. The first author is also grateful to Thailand International Cooperation Agency (TICA), 
Ministry of Foreign Affairs of the Kingdom of Thailand for providing the scholarship to study for the Master of Science degree in Bioscience for Sustainable Agriculture program at ASAT, SU, Cha-Am, Phetchaburi, Thailand. Last, but not least, the authors would like to thank the reviewers for critical comments.

\section{REFERENCES}

Aguilar-González AE, Palou E, López-Malo A 2015. Antifungal activity of essential oils of clove (Syzygium aromaticum) and/or mustard (Brassica nigra) in vapor phase against gray mold (Botrytis cinerea) in strawberries. Innovative Food Science \& Emerging Technologies 32: 181-185. https://doi.org/10.1016/j.ifset.2015.09.003

Albores LC, Baños SB, Herrera JM, Necha LB, López MH, Hernández AC 2014. Morphological and molecular characterization of pathogenic isolates of Fusarium spp. obtained from gladiolus corms and their sensitivity to Jatropha curcas L. oil. African Journal of Microbiology Research 8: 724-733. $\underline{\text { https://doi.org/10.5897/ }}$ AJMR2013.6413

Ambindei WA, Jazet PMD, Tatsadjieu LN, Priya P, Manilal V, Krishnakumar B, Zollo PHA 2017. Effect of the essential oils of Thymus vulgaris, Cinnamomum zeylanicum and Mentha piperita on fungal growth and morphology. African Journal of Biotechnology 16: 388-399. https:// doi.org/10.5897/AJB2017.15881

Arrebola E, Sivakumar D, Bacigalupo R, Korsten L 2010. Combined application of antagonist Bacillus amyloliquefaciens and essential oils for the control of peach postharvest diseases. Crop Protection 29: 369377. https://doi.org/10.1016/j.cropro.2009.08.001

Ashfaq M, Mubashar U, Haider M, Ali M, Ali A, Sajjad M 2017. Grain discoloration: An emerging threat to rice crop in Pakistan. Journal of Animal and Plant Sciences 27: 696707.

Avila-Sosa R, Palou E, Munguía MTJ, Nevárez-Moorillón GV, Cruz ARN, López-Malo A 2012. Antifungal activity by vapor contact of essential oils added to amaranth, chitosan, or starch edible films. International Journal of Food Microbiology 153: 66-72. https://doi. org/10.1016/j.ijfoodmicro.2011.10.017

Azhdarzadeh F, Hojjati M 2016. Chemical composition and antimicrobial activity of leaf, ripe and unripe peel of bitter orange (Citrus aurantium) essential oils. Nutrition and Food Sciences Research 3: 43-50. https://doi. org/10.18869/acadpub.nfsr.3.1.43

Bakkali F, Averbeck S, Averbeck D, Idaomar M 2008. Biological effects of essential oils-a review. Food and Chemical Toxicology 46: 446-475. https://doi.org/10.1016/j. fct.2007.09.106

Baser KHC, Buchbauer G 2015. Handbook of essential oils: science, technology, and applications. 1st ed, Boca Raton, FL, USA: CRC Press. https://doi.org/10.1201/b19393-2

Beg AZ, Ahmad I 2002. In vitro fungitoxicity of the essential oil of Syzygium aromaticum. World Journal of Microbiology and Biotechnology 18: 317-319. https:// doi.org/10.1023/A:1015242901360

Boukhatem MN, Ferhat MA, Kameli A, Saidi F, Kebir HT 2014.
Lemon grass (Cymbopogon citratus) essential oil as a potent anti-inflammatory and antifungal drugs. Libyan Journal of Medicine 9: 25431. https://doi.org/10.3402/ ljm.v9.25431

Bullangpoti V 2009. Botanical insecticides in Thailand: hopes and hindrances. Biopesticides International 5: 75-99.

Burt S 2004. Essential oils: their antibacterial properties and potential applications in foods--a review. International Journal of Food Microbiology 94: 223-253. https://doi. org/10.1016/j.ijfoodmicro.2004.03.022

CABI 2020. Curvularia (black kernel). In: Invasive Species Compendium. Wallingford, UK: CAB International. https://www.cabi.org/isc/datasheet/17046

Corsini E, Birindelli S, Fustinoni S, De Paschale G, Mammone T, Visentin S, Galli CL, Marinovich M, Colosio C 2005. Immunomodulatory effects of the fungicide Mancozeb in agricultural workers. Toxicology and Applied Pharmacology 208: 178-185. https://doi.org/10.1016/j. taap.2005.02.011

da Silva Gündel S, dos Reis TR, Copetti PM, Favarin FR, Sagrillo MR, da Silva AS, Segat JC, Baretta D, Ourique AF 2019. Evaluation of cytotoxicity, genotoxicity and ecotoxicity of nanoemulsions containing Mancozeb and Eugenol. Ecotoxicology and Environmental Safety 169: 207-215. https://doi.org/10.1016/j.ecoenv.2018.11.023

Dhananjayan V, Ravichandran B 2018. Occupational health risk of farmers exposed to pesticides in agricultural activities. Current Opinion in Environmental Science \& Health 4: 31-37. https://doi.org/10.1016/j. coesh.2018.07.005

Dutta A, Hussain S 1959. Leaf spot of Rose caused by Curvularia lunata (Wakker) Boedijn. Current Science 28.

Edris AE, Farrag ES 2003. Antifungal activity of peppermint and sweet basil essential oils and their major aroma constituents on some plant pathogenic fungi from the vapor phase. Nahrung/Food 47: 117-121. https://doi. org/10.1002/food.200390021

Esper RH, Goncalez E, Marques MO, Felicio RC, Felicio JD 2014. Potential of essential oils for protection of grains contaminated by aflatoxin produced by Aspergillus flavus. Frontiers in Microbiology 5: 269. https://doi. org/10.3389/fmicb.2014.00269

FAO 2020. Global Information and Early Warning System on Food and Agriculturec (GIEWS), Country Brief, Thailand. Retrieved 25 May 2020, from, updated 20-May-2020: http://www.fao.org/giews/countrybrief/country/ THA/pdf/THA.pdf

Goni P, López P, Sánchez C, Gómez-Lus R, Becerril R, Nerín C 2009. Antimicrobial activity in the vapour phase of a combination of cinnamon and clove essential oils. Food Chemistry 116: 982-989. https://doi.org/10.1016/j. foodchem.2009.03.058

Gummert M, Cabardo C 2013. Rice Storage. Retrieved 15 December 2019, from http://knowledgebank.irri.org/ images/docs/rice-storage-presentation.pdf

Handa S 2008. An overview of extraction techniques for medicinal and aromatic plants. In: Extraction technologies for medicinal and aromatic plants, International Centre for Science and High Technology, 
Trieste, Italy. Pp. 21-54.

Hashemi SMB, Khaneghah AM, de Souza Sant'Ana A 2017. Essential oils in food processing: chemistry, safety and applications, John Wiley \& Sons. https://doi. org/10.1002/9781119149392

Hossain F, Follett P, Vu KD, Harich M, Salmieri S, Lacroix M 2016. Evidence for synergistic activity of plant-derived essential oils against fungal pathogens of food. Food Microbiology 53: 24-30. https://doi.org/10.1016/j. $\underline{\text { fm.2015.08.006 }}$

Inouye S, Uchida K, Yamaguchi H 2001. In-vitro and in-vivo anti-Trichophyton activity of essential oils by vapour contact. Mycoses 44: 99-107. https://doi.org/10.1046/ j.1439-0507.2001.00618.x

Jantapan K, Poapolathep A, Imsilp K, Poapolathep S, Tanhan P, Kumagai S, Jermnak U 2017. Inhibitory effects of Thai essential oils on potentially aflatoxigenic Aspergillus parasiticus and Aspergillus flavus. Biocontrol Science 22: 31-40. https://doi.org/10.4265/bio.22.31

Ji H, Kim H, Beuchat LR, Ryu J-H 2019. Synergistic antimicrobial activities of essential oil vapours against Penicillium corylophilum on a laboratory medium and beef jerky. International Journal of Food Microbiology 291: 104-110. https://doi.org/10.1016/j. ijfoodmicro.2018.11.023

Jiang H, Wang J, Song L, Cao X, Yao X, Tang F, Yue Y 2016. GC $\times$ GC-TOFMS Analysis of essential oils composition from leaves, twigs and seeds of Cinnamomum camphora L. Presl and their insecticidal and repellent activities. Molecules 21: 423. https://doi.org/10.3390/ molecules 21040423

Jitjak W, Sanoamuang N 2019. The contamination of toxins produced by naturally occurring fungi in non-chemical rice products. International Journal of Agricultural Technology 15: 17-34.

Kim SW, Lee HR, Jang MJ, Jung CS, Park IK 2016. Fumigant toxicity of Lamiaceae plant essential oils and blends of their constituents against adult rice weevil Sitophilus oryzae. Molecules 21: 361. https://doi.org/10.3390/ molecules21030361

Kishore GK, Pande S, Harish S 2007. Evaluation of essential oils and their components for broad-spectrum antifungal activity and control of late leaf spot and crown rot diseases in peanut. Plant Disease 91: 375-379. https:// doi.org/10.1094/PDIS-91-4-0375

Klich M, Pitt J 1988. Differentiation of Aspergillus flavus from $A$. parasiticus and other closely related species. Transactions of the British Mycological Society 91: 99108. https://doi.org/10.1016/S0007-1536(88)80010-X

Kongtip P, Techasaensiri B, Nankongnab N, Adams J, Phamonphon A, Surach A, Sangprasert S, Thongsuksai A, Srikumpol P, Woskie S 2017. The impact of prenatal organophosphate pesticide exposures on Thai infant neurodevelopment. International Journal of Environmental Research and Public Health 14: 570. https://doi.org/10.3390/ijerph14060570

Krungsri R 2019. Thailand industry outlook 2019-21: Rice industry. Retrieved 17 March 2020, from https://www. krungsri.com/bank/getmedia/54e68479-172d-4bcabc66-ab768c85faa5/IO Rice 190814_EN_EX.aspx
Kumar D, Kalita P 2017. Reducing postharvest losses during storage of grain crops to strengthen food security in developing countries. Foods 6: 8. https://doi. org/10.3390/foods6010008

Laird K, Phillips C 2012. Vapour phase: a potential future use for essential oils as antimicrobials? Letters in Applied Microbiology 54: 169-174. https://doi.org/10.1111/ j.1472-765X.2011.03190.x

Lapmak K, Lumyong S, Wangspa R, Sardsud U 2009. Diversity of filamentous fungi on brown rice from Pattalung Province, Thailand. Journal of Agricultural Technology 5: 129-142.

Mandras N, Nostro A, Roana J, Scalas D, Banche G, Ghisetti V, Del Re S, Fucale G, Cuffini AM, Tullio V 2016. Liquid and vapour-phase antifungal activities of essential oils against Candida albicans and non-albicans Candida. BMC Complement and Alternative Medicine 16: 330. https://doi.org/10.1186/s12906-016-1316-5

Marin S, Sanchis V, RELL F, Ramos AJ, MACAN N 1998. Colonization of maize grain by Fusarium moniliforme and Fusarium proliferatum in the presence of competing fungi and their impact on fumonisin production. Journal of Food Protection 61: 1489-1496. https://doi. org/10.4315/0362-028X-61.11.1489

Mendoza J, Sabillón L, Martinez W, Campabadal C, HallenAdams H, Bianchini A 2017. Traditional maize postharvest management practices amongst smallholder farmers in Guatemala. Stored Products Research 71: 1421. https://doi.org/10.1016/j.jspr.2016.12.007

Nakahara K, Alzoreky NS, Yoshihashi T, Nguyen HT, Trakoontivakorn G 2013. Chemical composition and antifungal activity of essential oil from Cymbopogon nardus (citronella grass). Japan Agricultural Reseach Quarterly 37: 249-252. https://doi.org/10.6090/ jarq.37.249

Nazzaro F, Fratianni F, Coppola R, De Feo V 2017. Essential oils and antifungal activity. Pharmaceuticals (Basel) 10: 86. https://doi.org/10.3390/ph10040086

Nikkhah M, Hashemi M, Najafi HMB, Farhoosh R 2017. Synergistic effects of some essential oils against fungal spoilage on pear fruit. International Journal of Food Microbiology 257: 285-294. https://doi.org/10.1016/j. ijfoodmicro.2017.06.021

Nyongesa BW, Okoth S, Ayugi V 2015. Identification key for Aspergillus species isolated from maize and soil of Nandi County, Kenya. Advances in Microbiology 5: 205-229. https://doi.org/10.4236/aim.2015.54020

OECD/FAO 2019. OECD-FAO Agricultural Outlook 20192028, OECD Publishing, Paris/Food and Agriculture Organisation of the United Nations, Rome. 326 p.

Panuwet P, Prapamontol T, Chantara S, Thavornyuthikarn P, Montesano MA, Whitehead Jr RD, Barr DB 2008. Concentrations of urinary pesticide metabolites in small-scale farmers in Chiang Mai Province, Thailand. Science of the Total Environment 407: 655-668. https:// doi.org/10.1016/j.scitotenv.2008.08.044

Phumthum M, Srithi K, Inta A, Junsongduang A, Tangjitman K, Pongamornkul W, Trisonthi C, Balslev H 2018. Ethnomedicinal plant diversity in Thailand. Journal of Ethnopharmacology 214: 90-98. https://doi. 
org/10.1016/i.jep.2017.12.003

Pitt J, Hocking AD, Bhudhasamai K, Miscamble BF, Wheeler KA, Tanboon-Ek P 1993. The normal mycoflora of commodities from Thailand. 1. Nuts and oilseeds. International Journal of Food Microbiology 20: 211-226. https://doi.org/10.1016/0168-1605(93)90166-E

Pitt J, Hocking AD, Bhudhasamai K, Miscamble BF, Wheeler KA, Tanboon-Ek P 1994. The normal mycoflora of commodities from Thailand. 2. Beans, rice, small grains and other commodities. International Journal of Food Microbiology 23: 35-53. https://doi.org/10.1016/01681605(94)90220-8

Proctor RH, Desjardins AE, Moretti A 2009. Biological and chemical complexity of Fusarium proliferatum. The role of plant pathology in food safety and food security. Springer, Netherlands. Pp. 97-111. https://doi. org/10.1007/978-1-4020-8932-9 9

Seephueak P, Preecha C, Seephueak W 2019. The diversity of fungi associated with rice (Oryza sativa L.) from Nakhon Si Thammarat, Thailand. International Journal of Agricultural Technology 15: 485-500.

Siddiqua S, Anusha BA, Ashwini LS, Negi PS 2015. Antibacterial activity of cinnamaldehyde and clove oil: effect on selected foodborne pathogens in model food systems and watermelon juice. Journal of Food Science and Technology 52: 5834-5841. https://doi. org/10.1007/s13197-014-1642-x

Silva CdBd, Guterres SS, Weisheimer V, Schapoval EE 2008. Antifungal activity of the lemongrass oil and citral against Candida spp. Brazilian Journal of Infectious Diseases 12: 63-66. https://doi.org/10.1590/S141386702008000100014

Srisukh V, Tribuddharat C, Nukoolkarn V, Bunyapraphatsara N, Chokephaibulkit K, Phoomniyom S, Chuanphung S, Srifuengfung S 2012. Antibacterial activity of essential oils from Citrus hystrix (makrut lime) against respiratory tract pathogens. ScienceAsia 38: 212. https://doi. org/10.2306/scienceasia1513-1874.2012.38.212

Stević T, Berić T, Šavikin K, Soković M, Gođevac D, Dimkić I, Stanković S 2014. Antifungal activity of selected essential oils against fungi isolated from medicinal plant. Industrial Crops and Products 55: 116-122. https://doi. org/10.1016/j.indcrop.2014.02.011

Sukatta U, Haruthaithanasan V, Chantarapanont W, Dilokkunanant U, Suppakul P 2008. Antifungal activity of clove and cinnamon oil and their synergistic against postharvest decay fungi of grape in vitro. Kasetsart Journal (Natural Science) 42: 169-174.

Tadtong S, Watthanachaiyingcharoen R, Kamkaen N 2014. Antimicrobial constituents and synergism effect of the essential oils from Cymbopogon citratus and Alpinia galanga. Natural Product Communications 9: 277-280. https://doi.org/10.1177/1934578X1400900237

Tang X, Shao Y-L, Tang Y-J, Zhou W-W 2018. Antifungal activity of essential oil compounds (geraniol and citral) and inhibitory mechanisms on grain pathogens (Aspergillus flavus and Aspergillus ochraceus). Molecules 23: 2108. https://doi.org/10.3390/molecules23092108

Tansakul N, Limsuwan S, Böhm J, Hollmann M, Razzazi-Fazeli E 2013. Aflatoxins in selected Thai commodities. Food
Additives \& Contaminants: Part B 6: 254-259. https:// doi.org/10.1080/19393210.2013.812148

Tawatsin A 2015. Pesticides used in Thailand and toxic effects to human health. Medical Research Archives. https://doi.org/10.18103/mra.v0i3.176

Thobunluepop P, Pawelzik E, Vearasilp S 2008. Possibility of biological seed coating application on direct-seed rice production: Emphasis on plant productivity and environment awareness. Agricultural Science Journal 39: 449-452.

Thundiyil JG, Stober J, Besbelli N, Pronczuk J 2008. Acute pesticide poisoning: a proposed classification tool. Bulletin of the World Health Organization 86: 205-209. https://doi.org/10.2471/BLT.08.041814

Tran-Dinh N, Pitt JI, Markwell PJ 2014. Selection of nontoxigenic strains of Aspergillus flavus for biocontrol of aflatoxins in maize in Thailand. Biocontrol Science and Technology 24: 652-661. https://doi.org/10.1080/095 83157.2014.888398

Tsedaley B, Adugna G 2016. Detection of Fungi Infecting Maize (Zea mays L.) Seeds in different storages around Jimma, Southwestern Ethiopia. Journal of Plant Pathology \& Microbiology 07: 1-6. https://doi. org/10.4172/2157-7471.1000338

Tyagi AK, Malik A 2011. Antimicrobial potential and chemical composition of Eucalyptus globulus oil in liquid and vapour phase against food spoilage microorganisms. Food Chemistry 126: 228-235. https:// doi.org/10.1016/j.foodchem.2010.11.002

Velázquez-Nuñez MJ, Avila-Sosa R, Palou E, López-Malo A 2013. Antifungal activity of orange (Citrus sinensis var. Valencia) peel essential oil applied by direct addition or vapor contact. Food Control 31: 1-4. https://doi. org/10.1016/j.foodcont.2012.09.029

Venables WN, Smith DM, R CT 2019. An Introduction to R Notes on R: A Programming Environment for Data Analysis and Graphics version 3.1.0. 55-56.

Wang L, Jiang N, Wang D, Wang M 2019. Effects of essential oil citral on the growth, mycotoxin biosynthesis and transcriptomic profile of Alternaria alternata. Toxins 11: 553. https://doi.org/10.3390/toxins11100553

White TJ, Bruns T, Lee S, Taylor J 1990. Amplification and direct sequencing of fungal ribosomal RNA genes for phylogenetics, Elsevier. 315-322 p. https://doi. org/10.1016/B978-0-12-372180-8.50042-1

Zárybnický T, Boušová I, Ambrož M, Skálová L 2018. Hepatotoxicity of monoterpenes and sesquiterpenes. Archives of Toxicology 92: 1-13. https://doi. org/10.1007/s00204-017-2062-2 